Personalidade Acadêmica Homenageada:

Augustus B. Cochran III (Agnes Scott College)

\title{
A INCONSTITUCIONALIDADE DA CRIMINALIZAÇÃO DO ABORTO: ANÁLISE DA ARGUIÇÃO DE DESCUMPRIMENTO DE PRECEITO FUNDAMENTAL № 442
}

UNCONSTITUTIONALITY OF CRIMINALIZATION OF ABORTION: ANALYSIS OF FUNDAMENTAL PRECEPT FAILURE ARGUATION No. 442

MARIA CAROLINA SOARES

Graduanda em Direito, modalidade integral, pela Escola Superior Dom Helder Câmara. Belo Horizonte-MG. E-mail: carolsoares.2105@hotmail.com.

RAFAELLA BÁRBARA FIUZA Graduanda em Direito, modalidade integral, pela Escola Superior Dom Helder Câmara. Belo Horizonte-MG. E-mail:rafafiuza@outlook.com

CAIO AUGUSTO SOUZA LARA Mestre e Doutor em Direito pela Faculdade de Direito da Universidade Federal de Minas Gerais - UFMG. Professor da Escola Superior Dom Helder Câmara. Pesquisador Associado ao Programa RECAJ-UFMG - Acesso à Justiça e Solução de Conflitos. Secretário de Comunicação do Conselho Nacional de Pesquisa e Pósgraduação em Direito - CONPEDI. Belo Horizonte-MG. E-mail: caiolarabh@yahoo.com.br. 


\section{Personalidade Acadêmica Homenageada:}

\section{Augustus B. Cochran III (Agnes Scott College)}

\section{RESUMO}

O tema-problema da pesquisa que se pretende desenvolver é a inconstitucionalidade do aborto presente na Arguição de Descumprimento de Preceito Fundamental no 442, proposta pelo Partido Socialismo e Liberdade (PSOL), em que é analisada a constitucionalidade dos arts. 124 e 126 do Código Penal. Em primeiro lugar, tem-se o debate constitucional sobre o caráter não absoluto e gradual da proteção jurídica ao desenvolvimento embrionário e fetal. Outrossim, há um grande embate moral que coíbe o aborto. Diante disso, esta pesquisa tem por objetivo geral analisar os direitos fundamentais violados com a criminalização do aborto. Como objetivos específicos, elencam-se: verificar a descriminalização do aborto em países democráticos; constatar a diferença de julgamento do Supremo Tribunal Federal na ADI 3.510 e ADPF 54; apurar o momento do início da vida humana no ordenamento jurídico brasileiro; pesquisar até que ponto a religião interfere nesse processo; investigar a classe de mulheres que mais são afetadas com os art. 124 e 126; reconhecer o déficit ao acesso à educação sexual, no Brasil, bem como examinar qual a razoabilidade constitucional do poder coercitivo do Estado para coibir o aborto. Nesse aspecto, esta pesquisa visa quebrar o senso comum e mostrar aos leigos que descriminalizar o aborto não é tornar a interrupção da gestação algo banal, mas, deixar que as mulheres decidam pelo seu próprio corpo e pelo seu próprio momento. Preceitos religiosos não podem ser tão fortes em um Estado laico como o Brasil. Diante disso, o Supremo Tribunal Federal cumpre seu dever ao julgar o tema nas ADPF 54 e a ADPF 442. Uma mulher a cada minuto faz aborto no Brasil, ou seja, o aborto é um fato na vida reprodutiva das mulheres brasileiras. Há uma relação entre mulheres de classe social mais baixa e o elevado número de abortos. Os dados empíricos sobre os efeitos da criminalização mostram que a lei penal não impede que abortos sejam feitos e, injustamente, força as mulheres comuns à ilegalidade e aos riscos da clandestinidade, favorecendo um mercado desregulado e arriscado de medicamentos e clínicas inseguras. O problema objeto da pesquisa é a criminalização do aborto além de não se fundamentar em um objetivo legítimo, não coíbe a prática do aborto. Diante disso, 


\section{Personalidade Acadêmica Homenageada:}

\section{Augustus B. Cochran III (Agnes Scott College)}

por quais razões o Supremo Tribunal Federal não descriminaliza o aborto? A partir das reflexões preliminares sobre o tema, é possível afirmar, inicialmente, que a criminalização do aborto coloca em risco a vida de muitas mulheres brasileiras, pois, apesar da coerção do Estado o aborto é uma realidade no país. Ademais, a inconstitucionalidade do aborto é discutida no Supremo Tribunal Federal na ADPF 442, em que a ideia neutralidade do Estado em aspectos morais é colocada em foco. Outrossim, o objetivo geral do trabalho é analisar a inconstitucionalidade dos art. 124 e 126 do Código Penal. A pesquisa que se propõe pertence à vertente metodológica jurídico-sociológica. No tocante ao tipo de investigação, foi escolhido, na classificação de Witker (1985) e Gustin (2010), o tipo jurídico-projetivo. O raciocínio desenvolvido na pesquisa será predominantemente dialético. De acordo com a técnica de análise de conteúdo, afirma-se que trata-se de uma pesquisa teórica, o que é possível a partir da análise de conteúdo dos textos doutrinários, normas e demais dados colhidos na pesquisa. Como conclusão parcial do trabalho, tem-se que a criminalização do aborto é inconstitucional e há um grande moralismo por trás da não descriminalização de tal fenômeno social. Além disso, a ilicitude do aborto mata muitas mulheres no país e constitui um grave problema de saúde pública.

PALAVRA-CHAVE: Descriminalização; Aborto; Supremo Tribunal Federal.

\section{REFERÊNCIAS}

BRASIL. SUPREMO TRIBUNAL FEDERAL. Arguição de Descumprimento de Preceito Fundamental 442. Disponível em: https://www.conjur.com.br/dl/psol-stfdescriminalize-abortomeses.pdf?fbclid=IwAR3KdN9sbF5hRrZZ2pBefl_LUPg2LQvZbELL4YQLPSr7mBjiD 7n5I0-9tJg Acesso em: 22 de maio de 2019

BRASIL. SUPREMO TRIBUNAL FEDERAL. Ação Direta de Inconstitucionalidade 3.510. Relator: Min. Ayres Britto. Brasília, DF, 29 maio 2008. Diário da Justiça Eletrônico, Brasília, DF, n. 96, 28 maio 2010. Disponível em: 
Personalidade Acadêmica Homenageada:

Augustus B. Cochran III (Agnes Scott College)

http://www.stf.jus.br/portal/peticaolnicial/verPeticaolnicial.asp?base=ADIN\&s1=3510 \&processo=3510. Acesso em 8 mai 2019.

BRASIL. SUPREMO TRIBUNAL FEDERAL. Ementa do voto-vista vencedor do Ministro Luís Roberto Barroso no Habeas Corpus no 124.306. Relator: Min. Marco Aurélio. Brasília, DF, 29 de novembro de 2016. Disponível em: https://www.stf.jus.br/arquivo/cms/noticiaNoticiaStt/anexo/HC124306LRB.pdf?fbclid=I wAR2u2t4EpkVXRDOV1G4FuOdAR5vUCyFha0_R4sbseg2jmgBQf8MOX6mdlqY Acesso em: 08 mai. 2019.

BRASIL. SUPREMO TRIBUNAL FEDERAL. Voto de Celso de Mello no Habeas Corpus no 84.025/RJ. Relator: Min. Joaquim Barbosa. Brasília, DF, 04 de março de 2004. Diário da Justiça, Brasília, DF, 18 mar. 2004. Disponível em: http://www.stf.jus.br/portal/cms/verNoticiaDetalhe.asp?idConteudo=337860 Acesso em: 08 mai. 2019.

GUSTIN, Miracy Barbosa de Sousa; DIAS, Maria Tereza Fonseca. (Re)pensando a pesquisa jurídica: teoria e prática. 3․a . ed. Belo Horizonte: Del Rey, 2010.

ROCHA, Cármen Lúcia Antunes. Vida digna: direito, ética e ciência (os novos domínios científicos e seus reflexos jurídicos). In: ROCHA, Cármen Lúcia Antunes (Coord.). O direito à vida digna. Belo Horizonte: Fórum. p. 160-161.

SARMENTO, Daniel. Legalização do aborto e Constituição. Revista de Direito Administrativo, Salvador, v. 240, p. 43-82, abr./jun. 2005. Disponível em: http://pfdc.pgr.mpf.mp.br/atuacao-e-conteudos-deapoio/publicacoes/direitos-sexuaisereprodutivos/aborto/legalizacao_do_aborto_e_constituicao_daniel_sarmento.pdf. Acesso em: 8 maio 2019.

TOZZI, Piero A.; MARCILESE, Sebastián; GONZÁLES Rossana Muga. El activismo judicial en Latino América: análisis a raíz de la reciente jurisprudencia argentina proaborto. Revista Jurídica UNICURITIBA, Curitiba v.3, n.40, 2015. Disponível em: http://revista.unicuritiba.edu.br/index.php/RevJur/article/view/1358. Acesso em: 21 maio 2019.

WITKER, Jorge. Como elaborar uma tesis en derecho: pautas metodológicas y técnicas para el estudiante o investigador del derecho. Madrid: Civitas, 1985. 